\title{
Acute idiopathic interstitial myocarditis: case report with special reference to morphological characteristics of giant cells
}

\author{
M TANAKA, R ICHINOHASAMA, Y KAWAHARA, Y ESAKI, ${ }^{*}$ K HIROKAWA, $\dagger$ \\ K OKISHIGE, $\ddagger$ Y TANAKA
}

From the Pathological Anatomical Services, Tokyo Metropolitan Hiroo General Hospital, and the *Tokyo Metropolitan Geriatric Hospital, the †Department of Pathology, Tokyo Metropolitan Institute of Gerontology, and the $\ddagger$ Oume Municipal General Hospital, Tokyo, Japan

SUMMARY Necropsy findings of an acute fatal case of idiopathic interstitial myocarditis were reported. The patient was a 33 year old housewife who had acute cardiac failure on the sixteenth day after the onset of the disease. Necropsy showed important pathological changes confined to the heart. Both ventricles were affected by confluent granulomas with an ill defined patchy appearance. Histologically these lesions consisted of round cells, histiocytes, eosinophils and myogenic giant cells. The findings were compatible with those of interstitial myocarditis associated with a proliferation of giant cells. Both atriums were also affected to a minor extent, detectable only by histological examination. Electron microscopy and cytochemistry showed that most giant cells noted in the lesion showed myofibrils and primary lysosomes in the cytoplasm. Giant cells were positive for myoglobin.

Though the macrophage origin of the giant cell in this disorder has been emphasised in a recent report, these cytological results suggest that giant cells observed in the cardiac granulomatous lesions of this case were mainly myogenic in origin.

Various infectious disorders are known to induce granulomatous lesions in the myocardium, which are associated with the appearance of giant cells. ${ }^{12}$ These disorders are not necessarily fatal, and some cases can be cured. An acute idiopathic form of interstitial myocarditis, a rare primary disorder of the heart, is often fatal and is accompanied by extensive degeneration and necrosis of the myocardium and a granuloma like lesion consisting of round cell infiltration, histiocytosis, and eosinophilia. A proliferation of giant cells of both histiocytic and myogenic type, with a certain variation in number according to the case, is also often noted in this disorder. ${ }^{2}$ The important change is confined to the heart and has been named as either isolated or idiopathic interstitial myocarditis. Because of the unique morphology of its myocardial granulomatous lesion, the disorder is commonly referred to as giant cell myocarditis. About 40 cases of an acute idiopathic form of giant cell myocarditis have been reported worldwide. ${ }^{34}$

Accepted for publication 27 May 1986
Careful review of these reported cases showed that nearly half were probably cardiac sarcoidosis. ${ }^{5}$ Characteristic giant cells observed in acute idiopathic interstitial myocarditis may originate from degenerating myocardial cells and myocardial interstitial histiocytes, ${ }^{1}$ their origin, however, is still somewhat controversial. Filamentous materials resembling degenerated myofibrils detectable ultrastructurally in these cells ${ }^{6}$ were interpreted either as degenerating myofibrils of the myocardial cell ${ }^{7}$ or phagocytised myofibrils of macrophages. ${ }^{8-10}$ Histochemically, the lysosomal activity of these giant cells did not help to distinguish their origin. ${ }^{10} \mathrm{~A}$ recent immunohistochemical study showed the presence of antimacrophage and anti-Leu 3a (anti-T cell) antigens in giant cells and suggested that they originated from macrophages. ${ }^{10}$

This paper adds a further case to the reported cases of acute idiopathic interstitial myocarditis and presents evidence for the myogenic origin of giant cells, particularly on the basis of their ultrastructural and immunohistological characteristics. 


\section{Case report}

\section{CLINICAL HISTORY}

A 33 year old Japanese housewife had been healthy and had no history of allergic reaction to commonly prescribed drugs. She had no history of recent travel abroad. Her husband and two children were all healthy. In September 1984 she felt discomfort in the espigastric region after breakfast. On a visit to a neighbouring hospital, cardiomegaly and arrhythmia were pointed out. She then developed syncope for five minutes when she went upstairs at home. She was immediately taken to a local hospital. Electrocardiography showed an increase in S-T segment in II, III, aVf and V1-2, premature atrial contraction, and premature ventricular contraction and sinus tachycardia (120/minute). Digitalis and lidocaine were ineffective. She was transferred to Oume Municipal General Hospital. On admission, her physical condition was as follows: body temperature $36.7^{\circ} \mathrm{C}$; cardiac rate $96 /$ minute; respiratory rate 14 /minute; blood pressure $90 / 70 \mathrm{~mm} \mathrm{Hg}$. Congestion of both lungs and enlarged cardiothoracic ratio $(67 \%)$ were found on chest radiography. Central venous pressure was slightly raised $(17 \mathrm{~cm}$ water). An electron cardiogram

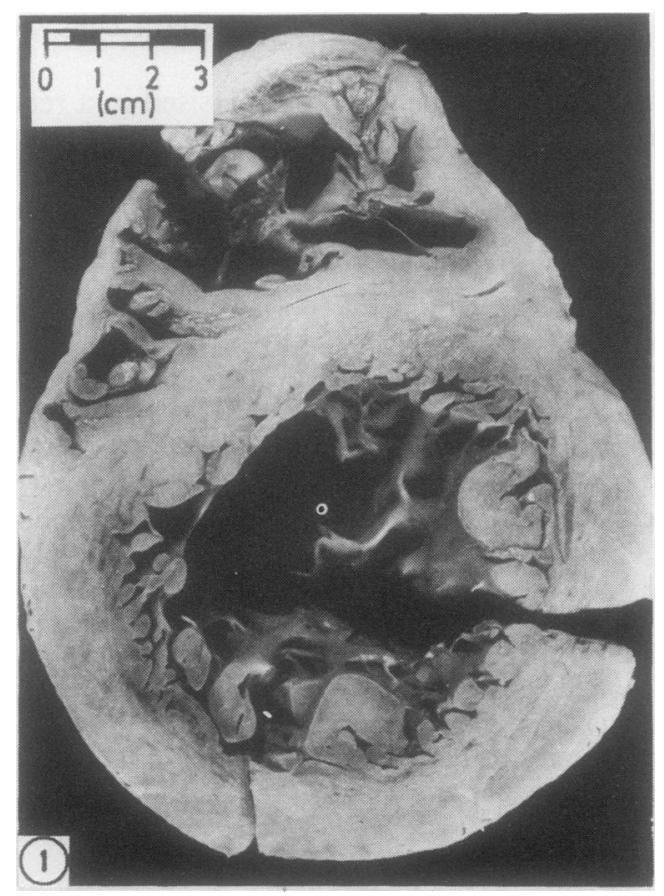

Fig 1 Cross section of ventricles. Note slight to moderate dilatation of bilateral ventricles with diffuse thinning of myocardium. No focal necrosis is observed. showed first degree A-V block (PQ interval $0.26 \mathrm{sec}-$ onds), disturbance of intraventricular conduction (QRS 0.09 seconds), and low voltage. Changes in serum enzyme activities were unimportant: creatine phosphokinase $107 \mathrm{IU} / 1$ (normal range $=24-170$ ), glutamic-oxaloacetic transaminase $28 \mathrm{IU} / 1$ (normal range: $0-40$ ), glutamic pyruvic transaminase $16 \mathrm{IU} / 1$ (normal range: $0-35$ ), except for slightly raised lactate dehydrogenase activities ( 751 Wroblewski units, normal range: 100-450). Data on peripheral blood showed (red blood cells $481 \times 10^{4}$, white cells 7600 , haemoglobin concentration $11.2 \mathrm{~g} / \mathrm{dl}$, haematocrit $33.5 \%$, platelets $16.1 \times 10^{4}$ ) and serum (rheumatic factor test negative, Treporema pullidum haemagglutination test negative, $\mathrm{C}$-reactive protein $1+$ ) showed no clinically important changes. Tests for tuberculin and Kveim reactions and estimations of antibody titres for viruses were not performed. Primary myocardial disease was suspected clinically, and the patient was conservatively treated by furosemide (80 $\mathrm{mg} /$ day) and dopamine (4-5 $\mu \mathrm{g} / \mathrm{kg} / \mathrm{minute})$. Right pneumothorax occurred and a continuous drainage was carried out. The pneumothorax improved four days later. Ventricular tachycardia (150/minute) then appeared and bradycardia followed (40/minute). Her

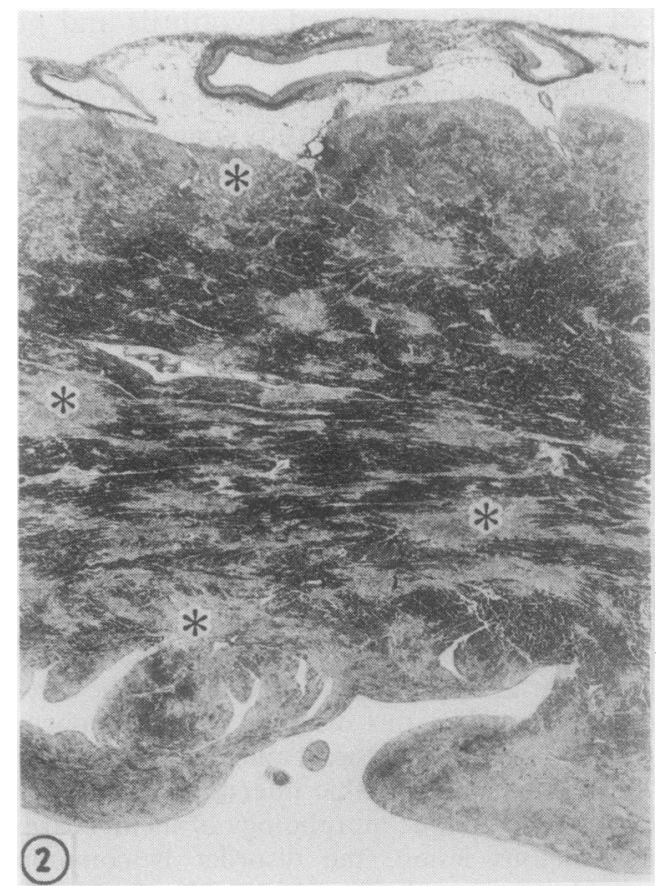

Fig 2 Low power view of part of left ventricle showing diffusely distributed patchy granulomas (*). Changes are important at external myocardial layer adjacent to epicardial fatty tissue. Endocardial side is at the bottom. (Azan stain.) $\times 8$. 
blood pressure became unmeasurable. A transient pacemaker was inserted but she died on September 21, 1984, 16 days after the onset of the disease.

\section{Pathology}

Necropsy was carried out two and a half hours after death. Notable pathological changes were confined to the heart. No clinically important changes were observed in other viscera.

The heart weighed $320 \mathrm{~g}$. There was a small amount of pericardial effusion $(60 \mathrm{ml})$ without apparent signs of pericarditis. Both ventricles were moderately dilated. The volume of the cardiac chambers was measured by a clay moulding method, and the data obtained were as follows: left ventricle $57.8 \mathrm{ml}$; right ventricle $72.9 \mathrm{ml}$; left atrium $28.1 \mathrm{ml}$; right atrium $49.7 \mathrm{ml}$. The wall thickness of the heart was at the low limit of the normal range: left ventricle $8.0 \mathrm{~mm}$; right ventricle $2.0-2.5 \mathrm{~mm}$. The circumference of the valvula annuli was within the normal range. No abnormality was found in any cardiac valve. Both coronary arteries showed minimal sclerosis. A bean sized fresh thrombus was attached to the endocardium of the left ventricular apex. On the cut surface, patchy lesions of

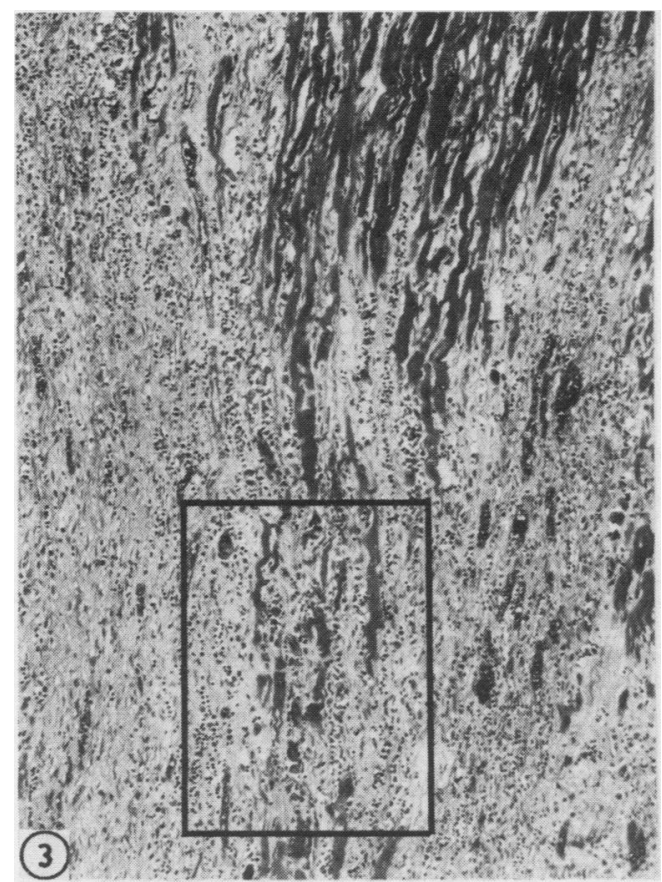

Fig 3 General view of granulomatous changes observed adjacent to degenerating myocardial cells (right upper corner). Details of cellular reaction in marked area of this picture are shown in fig 4. (Haematoxylin and eosin.) $\times 155$. up to a rice grain size, which were vaguely bordered and appeared greyish-white in colour, were spread diffusely and occupied about one third to a half of bilateral ventricle volumes (figs 1 and 2). Overall, neither scars nor necrotic foci were detectable in the myocardium.

Histologically patchy lesions were noted throughout the myocardium and consisted of granulomas of various sizes spread extensively through both ventricles (figs 2-4), the left atrium slightly, and the right atrium only at the appendage. The disease in both ventricles manifested itself more noticeably in the myocardium of the epicardial side; the epicardial fat tissue was only partially affected (fig 2). Papillary muscles of both ventricles were affected. No granulomatous lesions were noted in the chorda tendinae and cardiac valves. Major cellular elements found in the granulomatous lesions were small to medium sized lymphocytes and histiocytes (figs 3 and 4). A moderate number of eosinophils and plasma cells were also noted, but almost no neutrophils. Multinucleated giant cells of $25-90 \times 10-20 \mu \mathrm{m}$ in size, having up to 20 nuclei were found throughout the granulomatous foci, particularly at the periphery where a close contact to undamaged myocardial cells was speculated. In

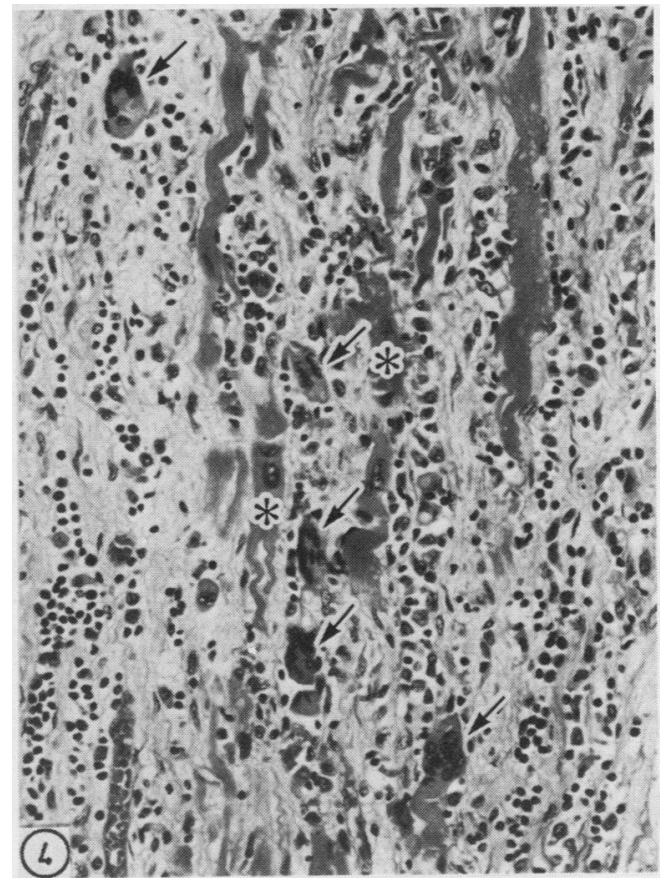

Fig 4 Granulomatous changes consisted of round cells, fibroblasts, and giant cells (arrow). Giant cells are commonly seen at parallel to degenerating myocardial cells $\left({ }^{*}\right)$. (Haematoxylin and eosin.) $\times 185$. 
granulomatous foci atrophy, swelling, and degeneration of muscle fibres were common (figs 3 and 4). Proliferation of fibroblasts and capillaries and new deposition of collagen were evident. Neither vasculitis nor neuritis was noted.
Neither granulomatous lesions nor angitis were found in other organs. A $2 \times 1 \mathrm{~cm}$ sized scar was found in the right apex of the lung $(230: 310 \mathrm{~g})$ (weight of left lung $230 \mathrm{~g}$, right lung $310 \mathrm{~g}$ ); focal lymphocytosis was also noted. Organising pneumonia of right

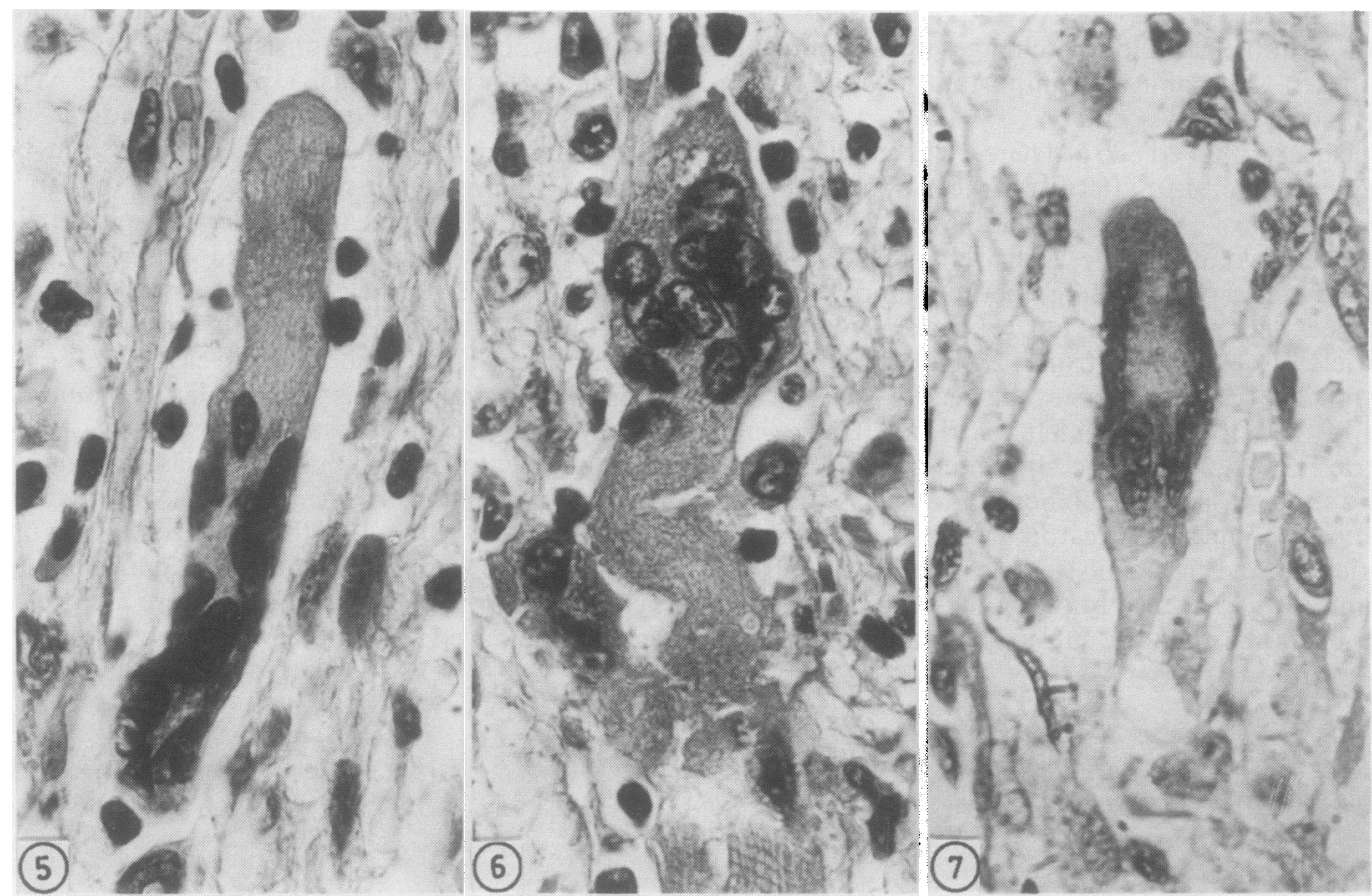

Figs 5-7 Three types of multinuclear giant cells distinguished by nuclear position. Figs 5 and 6 were taken from haematoxylin and eosin stained sections, and fig 7 was taken from immunohistochemically stained section (PAP method, myoglobin.) $\times 820$.

Fig 5 Elongated type which often communicates with degenerating muscle cells.

Fig 6 Giant cell with centrally located multiple nuclei.

Fig 7 Giant cell with circularly arranged multiple nuclei. Myoglobin is weakly positive in upper part of the cytoplasm of giant cell.

Table 1 Immunohistochemical differences of giant cells shown by PAP method

\begin{tabular}{|c|c|c|c|c|c|c|c|c|}
\hline & Types of gian & cells & $\begin{array}{l}\text { nce in \%) } \\
I I\end{array}$ & III & Sarcoidosis & Langhans' type & Foreign body type & Touton type \\
\hline Myoglobin* & $\begin{array}{l}\text { (A) } 52 \\
\text { (B) } 32 \\
\text { (C) } 16\end{array}$ & $\begin{array}{r}24 \\
8 \\
0\end{array}$ & $\begin{array}{l}22 \\
14 \\
10\end{array}$ & $\begin{array}{c}6 \\
10 \\
6\end{array}$ & $(-)$ & $(-)$ & $(-)$ & $(-)$ \\
\hline Lysozyme* & $\begin{array}{l}\text { (A) } 8 \\
\text { (B) } 42 \\
\text { (C) } 50\end{array}$ & $\begin{array}{r}0 \\
6 \\
20\end{array}$ & $\begin{array}{r}4 \\
26 \\
18\end{array}$ & $\begin{array}{r}4 \\
10 \\
12\end{array}$ & $(++)$ & $(+++)$ & $(+)-(-)$ & $(++)-(+)$ \\
\hline $\begin{array}{l}\operatorname{IgG} * * \\
\operatorname{IgA}^{* *} \\
\operatorname{IgM}^{* *}\end{array}$ & $\begin{array}{l}(++)-(+) \\
(++)-(-) \\
(+)-(-)\end{array}$ & & & & $\begin{array}{l}(+) \\
(+) \\
(+)\end{array}$ & $\begin{array}{l}(+) \\
(-) \\
(-)\end{array}$ & $\begin{array}{l}(++)-(-) \\
(++)-(-) \\
(++)-(-)\end{array}$ & $\begin{array}{l}(+)-(-) \\
(+)-(-) \\
(+)-(-)\end{array}$ \\
\hline
\end{tabular}

Sources of reagents: ${ }^{*}$ DakoPatts Inc, ${ }^{* *}$ Boehringerwerke. $\mathbf{A}, \mathbf{B}$, and $\mathbf{C}(\mathbf{A}=$ definitely positive, $\mathbf{B}=\mathbf{f a i n t l y}$ positive, $\mathbf{C}=$ negative $)$, staining intensity $=(-)$ negative, $(+)$ weakly positive, $(+t)$ moderately positive, $(t+t)$ strongly positive. 


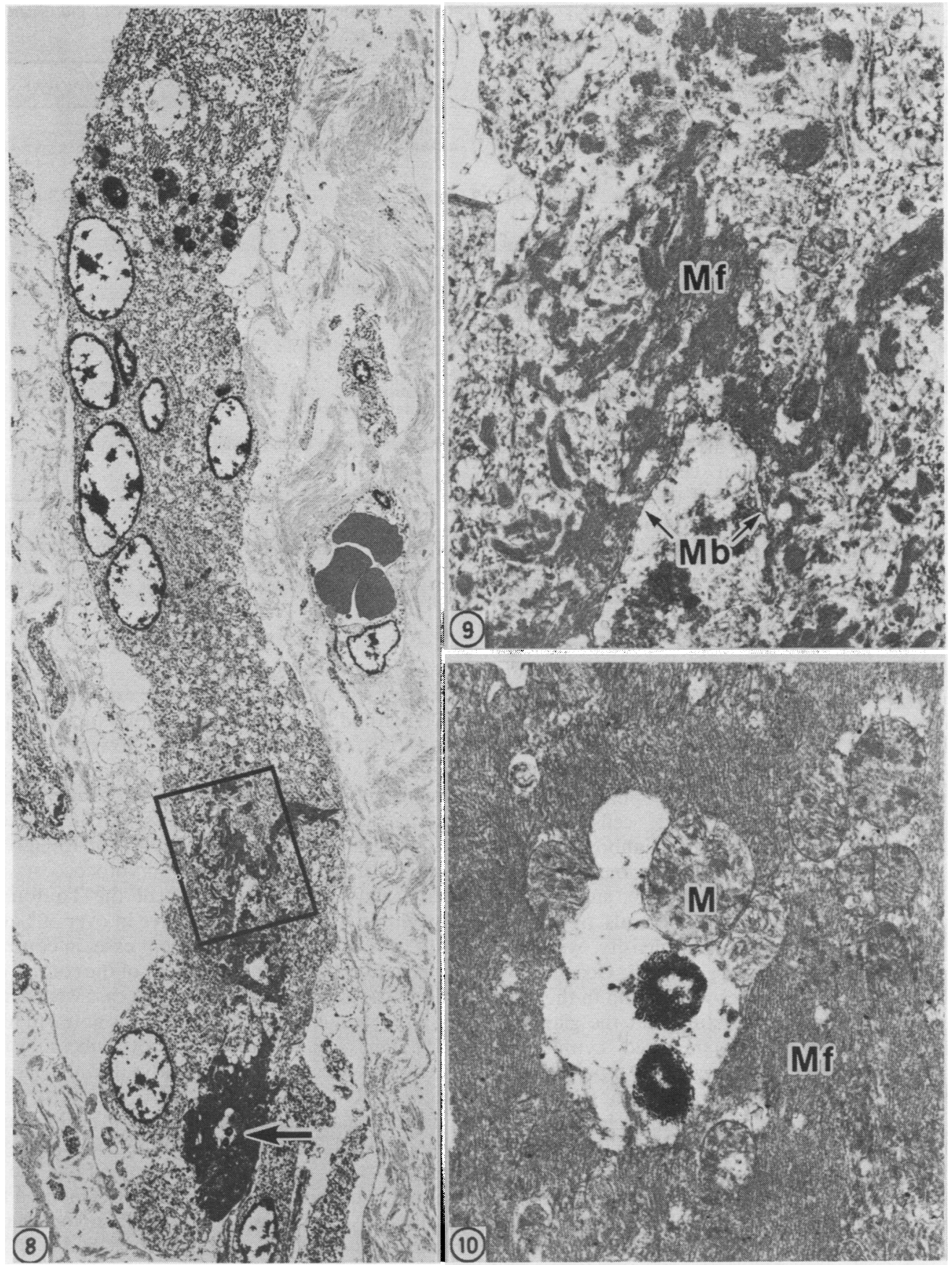

Fig 8 Low power view of multinucleated giant cell of elongated type. Cell was preserved poorly due to cadaverous change. Parts of cytoplasm, (square) and (arrow) were further enlarged and are shown in figs 9 and 10, respectively. (Lead citrate and uranyl acetate.) $\times 1960$.

Fig 9 Higher magnification of cytoplasmic portion of giant cell shown in fig 8. Myofibrils (Mf) in cytoplasm are shown. Mb: cell membrane. $\times 8480$.

Fig 10 Dense structure of cytoplasm consisting of condensed (degenerating) myofibrils (Mf). $M=$ mitrochondria. $\times 17000$. 
segment 5 of the lung was also noted. Slight eosinophilia was noted in the muscle layer of the gastric antrum. Numerous fibrin thrombi in the liver $(960 \mathrm{~g})$ and a small number of pulmonary vessels suggested that disseminated intravascular coagulation might have occurred at the final stage.

CHARACTERISTICS OF GIANT CELLS

Morphological characteristics in histology Most giant cells observed in myocardial granulomas of this case resembled either foreign body or myogenic giant cells. Their positions seemed to parallel those of the muscle cells (fig 4). Three types of giant cells were distinguished in the granulomas: type I-giant cells with elongated cytoplasm either arranged in parallel or connecting directly with muscle fibres (fig 5); type II-giant cells with centrally arranged multiple nuclei (fig 6); and type III-giant cells with circularly arranged multiple nuclei (fig 7). Table 1 shows a rough estimation of their incidence in 100 giant cells. With periodic acid Schiff stain the cytoplasm of giant cells seemed to be rather pink. Lipofuscin granules, which could suggest a myogenic origin for the giant cells, were often noted at the paranuclear area.

Electron microscopy (figs 8-10) The tissue was poorly preserved due to cadaverous changes. Multinucleated giant cells (fig 8), however, with elongated cytoplasm (about $80 \mu \mathrm{m}$ in length) that contained myofibrils (fig 9) were easily detected. Giant cells were located adjacent to degenerating muscle fibres, which appeared condensed and osmiophilic (fig 10). Myofibrils of degenerating muscle cells extended occasionally into the cytoplasm of neighbouring giant cells closely attached to a thin membrane of complicated infoldings (an intercalated disc), suggesting a myogenic origin. Filamentous materials of 12.5 to $25 \mathrm{~nm}$ in thickness, with a sparse density, were also seen in the cytoplasm of the giant cell. Occasionally more than a pair of centrioles were found in the cytoplasm near the nuclei, suggesting that the giant cell was formed either by an impaired cytoplasmic division or cell fusion. There were two types of granules, one consisting of highly osmiophilic granules of 100 to $200 \mathrm{~nm}$ in diameter found in mitochondria, and the other consisting of low osmiophilic granules of 200 to $500 \mathrm{~nm}$ in diameter with a halo in the cytoplasm. The second type may have been the primary lysosome. Most rounded form giant cells showed ultrastructural characteristics similar to those of the elongated form, except that numerous lysosomes, both primary and secondary types, were found in the cytoplasm of some cells which had a few filamentous materials.

Immunohistochemistry (tables 1 and 2) Paraffin embedded tissues were examined by both peroxidaseantiperoxidase (table 1) and avidin-biotin-peroxidase
Table 2 Immunohistochemical markers of giant cells shown by $A B C$ method

\begin{tabular}{|c|c|}
\hline Markers & Reactions \\
\hline $\begin{array}{l}\text { Antihuman rabbit } \\
\alpha \text { 1-antichymotrypsin } \\
\alpha \text { 1-antitrypsin }\end{array}$ & $\begin{array}{l}(++)-(+) \\
(++)-(+)\end{array}$ \\
\hline $\begin{array}{l}\text { CEA }^{1} \\
\text { Desmin }^{1} \\
\text { Factor VIII }^{1} \\
\text { Ferritin }^{1} \\
\text { Fibronectin } \\
\text { Immunoglobulin }^{1} \\
\text { Keratin }^{1} \\
\text { Lactoferin }^{1}\end{array}$ & $\begin{array}{r}(-) \\
(-) \\
(-) \\
(-) \\
(+)(-) \\
(-) \\
(-)\end{array}$ \\
\hline $\begin{array}{l}\text { Lysozyme }^{1} \\
\text { Myoglobin }^{3} \\
\text { S-100 protein } \\
\text { Actin IgG (chicken) }\end{array}$ & $\begin{array}{r}(+)-(-) \\
(+)-(-) \\
(-) \\
(+)-(-)\end{array}$ \\
\hline $\begin{array}{l}\text { Antihuman mouse (monoclonal) } \\
\text { Myosin } \\
\text { Vimentin }^{7}\end{array}$ & $\begin{array}{r}(+)-(-) \\
(-)\end{array}$ \\
\hline
\end{tabular}

Sources of reagents: 1. DakoPatts Inc; 2. ZYM: Zymed Laboratory Inc, USA; 3. CPL: Cappel Laboratory Inc, USA; 4. Dr Matsuda, Department of Pathology, Yamagata University; 5. BTI: Biological Technologies Inc, USA; 6. Dr Nishikawa, Department of Pathology, Tokyo Women's Medical College, Japan; 7. LBS: Labsystem Oy, Finland.

complex (ABC) methods (table 2). Myoglobin, lysozyme, IgG, IgA and $\operatorname{IgM}$ were examined using the PAP method (table 1). For controls, various types of giant cells obtained from the following cases were examined: cardiac sarcoidosis (woman aged 21) for sarcoid giant cells; tuberculous lymphadenitis (man aged 27) for Langhans' giant cells; a tissue adjacent to oesophageal cancer (man aged 48) for foreign body giant cells; and a pulmonary cryptococcosis tissue (man aged 56) for giant cells of the Touton type. Myoglobin was definitely positive in over $50 \%$ of the giant cells observed in the present case, in contrast to the negative reaction of giant cells of the control cases. Half of the giant cells of the present case were negative for lysozyme. A similar tendency was noted in foreign body giant cells. Giant cells of both tuberculosis and sarcoidosis were strongly positive for the lysozyme reaction. Reactions to IgG, IgA, and IgM scarcely differed in giant cells of this case and of the controls. Sixteen cellular markers, including both myoglobin and lysozyme that had been studied by the PAP method, were analysed using the ABC method (table 2). In this study reactions to both myoglobin and lysozyme showed a similar pattern as had been noted with the PAP method. Giant cells of the present case were often equally positive in $\alpha 1$-antichymotrypsin and $\alpha 1$-antitrypsin, suggesting that some of the giant cells of the present case were of the macrophage origin. The importance of the rest of the markers tested was inconclusive and may serve only for a reference. 


\section{Discussion}

Acute idiopathic interstitial myocarditis, a diffuse type of Fiedler's myocarditis, ${ }^{11} 12$ has been distinguished from other forms of myocarditis observed in systemic disorders, including sarcoidosis, infectious, toxic, and allergic diseases. Because of the presence of occasional multinucleated giant cells in the myocardial lesions of this disease, ${ }^{13}$ the term isolated giant cell myocarditis is often applied, particularly in western reports. As the appearance of giant cells is related to non-specific myocardial lesions and is less common in acute idiopathic interstitial myocarditis the term giant cell myocarditis has not been used in this report.

The pathogenesis of this disease is unknown, ${ }^{14}$ but viral infections have been speculated. ${ }^{15}$ The acute fatal course of a case of an isolated cardiac lesion, compatible histologically with interstitial myocarditis, led to the final diagnosis. No granulomatous foci, which would suggest sarcoidosis, were detected in systemic organs examined both grossly and histologically. Looking at the available pathological anatomical data, our case resembles Friedler's myocarditis reported by Parrish ${ }^{16}$ and giant cell myocarditis reported by Suganuma et al $^{17}$; more extensive myocardial disease was reported in the former case.

In general, the term "giant cell myocarditis" is loosely applied to granulomatous myocardial lesions associated with the appearance of giant cells: any granulomatous lesion that affects the myocardium can expect to form giant cells. ${ }^{1418}$ The appearance of giant cells in myocardial ganulomatous lesions is possibly related to a reparatory process of damaged myocardial cells. Intervention of macrophages of both local (histiocytes) and blood (monocytes) origin, with certain variations in numbers, reflecting the stage of the disease, may occur.

In an earlier stage giant cells originating from degenerated or regenerating myocardial cells, or both, may predominate, in contrast to specimens of a later stage, in which macrophages may be observed more commonly following an advanced reparative process. It is likely that the controversial problem of the origin of giant cells in interstitial myocarditis is related, at least in a part, to morphological differences between granulomatous lesions, relating to the repair stage of the disease. The presence of giant cells in granulomatous lesions of the myocardium thus does not suggest any definitive pathogenesis. Rather, the topography of the granuloma, which is confined to the heart, may be more reliable and specific to define the disorder.

The origin of giant cells is one of the most popular topics concerning interstitial myocarditis. Both myogenic and macrophage origins for giant cells have already been considered. ${ }^{1214}$ Although a myogenic origin for giant cells is favoured, both foreign body and Langhans' type giant cells have also been suggested. ${ }^{14} 19$ The morphological grounds for the myogenic origin of giant cells are as follows: (i) parallel position of giant cells and muscle fibres; (ii) a direct contact between giant cells and muscle cells 17182021 ; (iii) the presence of a smooth transition from a giant cell to a muscle cell; (iv) myofibrils in the cytoplasm of giant cells ${ }^{622324}$; (v) lipofuscin granules in the cytoplasm of giant cells. ${ }^{13}$ These criteria have been drawn from data obtained during regeneration of the skeletal muscle after injury. ${ }^{43}$ Some argue that the latter three criteria are related to phagocytosis. ${ }^{1018}$

We morphologically classified the giant cell of this case into three types. The type I giant cell satisfies all morphological citeria stated above and thus can be regarded as a myogenic type. Though giant cells of the two other types also satisfy the criteria for the myogenic origin, the type II giant cells resemble foreign body giant cells. Morphological differences were seen between the type III giant cell and giant cells observed in tuberculosis and sarcoidosis. The myogenic origin of most giant cells observed in our case was further confirmed ultrastructurally and immunohistochemically. An electron microscopical examination showed a close association between degenerated muscle fibres and the cytoplasm of the giant cell, confirming earlier an observation made by Pyun et al. ${ }^{6}$ The presence of myoglobin was shown immunohistochemically in over $50 \%$ of giant cells in our case, suggesting that most of the giant cells were of myogenic origin.

Recently immunocytochemical methods have been applied to define the macrophage nature of giant cells observed in interstitial myocarditis. ${ }^{10}$ Although not tested in this study, Theaker et al ${ }^{10}$ showed two different antimacrophage antibodies (EMB 11 and KB 90) in giant cells using a monoclonal antibody method. They reported that both desmin and $\mathrm{Ki} 67$ were negative in giant cells, except for a positive $\mathrm{Ki} 67$ reaction in the nuclei of lymphocytes and mononuclear phagocytes. Lysozyme activity was nearly absent in our case, which agrees with the findings of most other cases reported, ${ }^{7810}$ except that a positive reaction was noted in one case. ${ }^{9}$ This case may be regarded as specific, as the giant cells of this case showed no elongated forms (type I of our case), no transitional forms to muscle cells, and a negative cytochemical reaction to myosin and creatine phosphokinase. Negative lysozyme activity, however, does not completely exclude a histiocytic origin for giant cells, because some macrophages are known to appear negatively. ${ }^{25}$ Cellular immunity is required to induce the lysozyme activity. ${ }^{8}$ Perhaps the positive lysozymal activity noted in that case ${ }^{9}$ was related to underlying 
immunological abnormality caused by chronic active hepatitis with positive antinuclear antibody.

We express our gratitude for the excellent technical help of the following technologists in the preparation of the histological, immunochemical, and electron microscopical specimens used in this study: Y Ootani and Y Hirahara of the Clinical Pathology Service, Oume Municipal General Hospital; Mr I Sakuma and Mrs Y Suzuki, the Pathological Anatomical Service, Tokyo Metropolitan Hiroo Hospital. We also acknowledge valuable advice and comments for case analysis from Dr S Otsu, Yokufūkai Geriatric Hospital, Tokyo, and Professor Morie Sekiguchi, the Heart Institute of Tokyo Women's Medical College, and Dr Y Matsui, Japan Red Cross Medical Center, Tokyo. We are indebted to Professor T Kasajima and Dr T Nishikawa, Second Department of Pathology, Tokyo Women's Medical College, for their kind help in immunohistochemical studies (ABC method) of the giant cells of this case. We also thank associate Professor J Patrick Barron of St Marianna University School of Medicine for his revision of the manuscript.

\section{References}

1 Pomerance A, Davies MJ. The pathology of the heart. Oxford: Blackwell Scientific Publications, 1975.

2 Becker AE. Myocarditis. In: Silver MD, ed. Cardiovascular pathology. Vol 1. New York: Churchill-Livingstone, 1983: 469-88.

3 Palmer HP, Michael IE. Giant-cell myocarditis with multiple organ involvement. Arch Intern Med 1965;116:444-7.

4 Davies MJ, Pomerance A, Teare RD. Idiopathic giant cell myocarditis-a distinct clinico-pathological entity. Br Heart J 1975;37:192-5.

5 Ooneda G, Mitomo H, Kato K, Kanai H, Yoshimoto T. Myocardial sarcoidosis (giant cell myocarditis). Report of a case with autopsy and a study on the nature of asteroid bodies. Transactiones Societatis Pathologicae Japonicae 1957; 46:838-54.

6 Pyun KS, Kim YH, Katzenstein RE, Kikkawa Y. Giant cell myocarditis. Light and electron microscopic study. Archives of Pathology 1970;90:181-8.

7 Tubbs RR, Sheibani K, Hawk WA. Giant cell myocarditis. Arch Pathol Lab Med 1980;104:245-6.
8 Ohno T, Tamaki N, Motoki K, Yamamoto K, Seki K. An autopsy case report of giant cell myocarditis with mediastinal lymphnode involvement. Shinzo 1983;15:91-6.

9 Rabson AB, Schoen FJ, Warhol MJ, Mudge GH, Collins Jr JJ. Giant cell myocarditis after mitral valve replacement: case report and studies of the nature of giant cells. Hum Pathol 1984;15:585-7.

10 Theaker JM, Gatter KC, Heryet A, Evans DJ, McGee JO'D. Giant cell myocarditis: evidence for the macrophage origin of giant cells. J Clin Pathol 1985;38:160-4.

11 Jarcho S. Fiedler on acute interstitial myocarditis (1899)-I. Am J Cardiol 1973;32:221-3.

12 Jarcho S. Fielder on acute interstitial myocarditis (1899)-II. $A m$ J Cardiol 1973;32:716-8.

13 Whitehead R. Isolated myocarditis. Br Heart J 1965;27:220-30.

14 McAllister HA, Ferrans VJ. Granulomas of the heart and blood vessels. In: Loauhin HL, ed. Pathology of granuloma. New York: Raven Press, 1983:75-123.

15 Sekiguchi M, Hiroe M, Take M, Hirosawa K. Clinical and histopathological profile of sarcoidosis of the heart and acute idiopathic myocarditis. Concepts through a study employing endomyocardial biopsy. II. Myocarditis. Jpn Circ J 1980; 44:264-73.

16 Parrish JA. Fiedler's myocarditis. Br Heart J 1965;27:458-61.

17 Suganuma T, Okada M, Sakai Y, Fujiwara M. An autopsy case of giant cell myocarditis. Shinshuu Igakkai Zasshi 1975; 23:149-55.

18 Dilling NV. Giant-cell myocarditis. J Pathol Bacteriol 1956; 71:295-300.

19 Sekiguchi M, Numao Y, Imai M, Furuie T, Mikami R. Clinical and histopathological profile of sarcoidosis of the heart and acute idiopathic myocarditis. Concept through a study employing endomyocardial biopsy. I. Sarcoidosis. Jpn Circ J 1980;44:249-63.

20 Langston JD, Wagman GF, Dickenman RC. Granulomatous myocarditis and myositis associated with thymoma. Archives of Pathology 1959;68:367-73.

21 Boeson K, Hansen BF. A case of giant cell myocarditis. Acta Me Scand 1981;210:521-2.

22 Peison B, Lowenstein EC. Giant-cell myocarditis. NY State J Med 1973:73:259-63.

23 Shimada N, Ishihara Y, Kojima A, Moriyasu K. Three cases of granulomatous myocarditis with giant cells. Acta Pathol Jpn 1967;17:503-15.

24 Tesluk H. Giant cell versus granulomatous myocarditis. Am J Clin Pathol 1956;26:1326-33.

25 Mason DY, Taylor CR. The distribution of muramidase (lysozyme) in human tissues. J Clin Pathol 1975;28:124-32.

Requests for reprints to: $\operatorname{Dr} M$ Tanaka, Pathological Anatomical Service, Tokyo Metropolitan Hiroo General Hospital, 2-34 Ebisu, Shibuya-ku, Tokyo 150, Japan. 